\title{
Paul Barber
}

\section{How to Get}

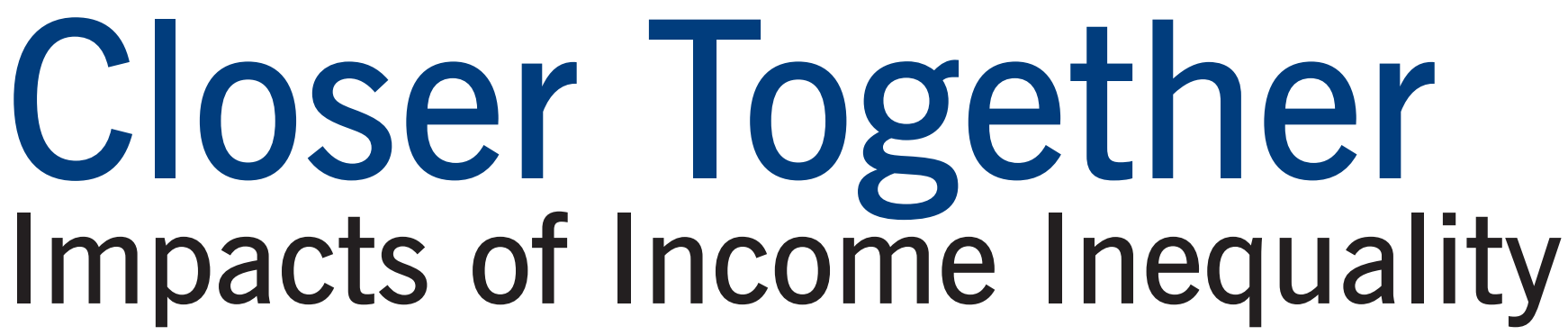

\section{and Policy Responses}

Inequality cannot simply be explained as wrong choices or behaviours. Inequality of resources and opportunity are powerful background forces. In order to get ahead, people need more equal access to resources - more income and wealth equality creates more equal opportunity for everyone in society. (National Equality Panel, 2010)

Professors Richard Wilkinson and Kate Pickett in The Spirit Level (2010) have documented the relationship between income inequality and health and social dysfunction across 25 developed countries including New Zealand, and summarised their findings in their Index of Health and Social Problems (IHSP). The results of this work show that New Zealand is performing poorly in comparison to countries with lower levels of income inequality. Their research has prompted debate in New Zealand (see Policy Quarterly issues of May and August 2011), and an example of the influence of their work can be seen in the references and measures chosen for the Treasury's Living Standards Framework released in May 2011.
This article briefly assesses the nature and impact of inequality in New Zealand using the evidence from the IHSP. It then discusses the policy options that need to be considered in order to reduce income inequality and the corresponding health and social impacts. The New Zealand Council of Christian Social Services (NZCCSS) has been working to analyse the impacts of income inequality through its Closer Together Whakatata Mai programme and detailed analysis of the data for each of the indicators in New Zealand can be found on the website www.closertogether.org.nz.

New Zealand is at a significant point in the overall social and economic policy debate. The lingering effects of the economic recession, plans for significant welfare reform, and a government committed to restraining expenditure growth, especially in health, welfare, housing and education, make it unlikely 
Figure 1: Index of health and social problems

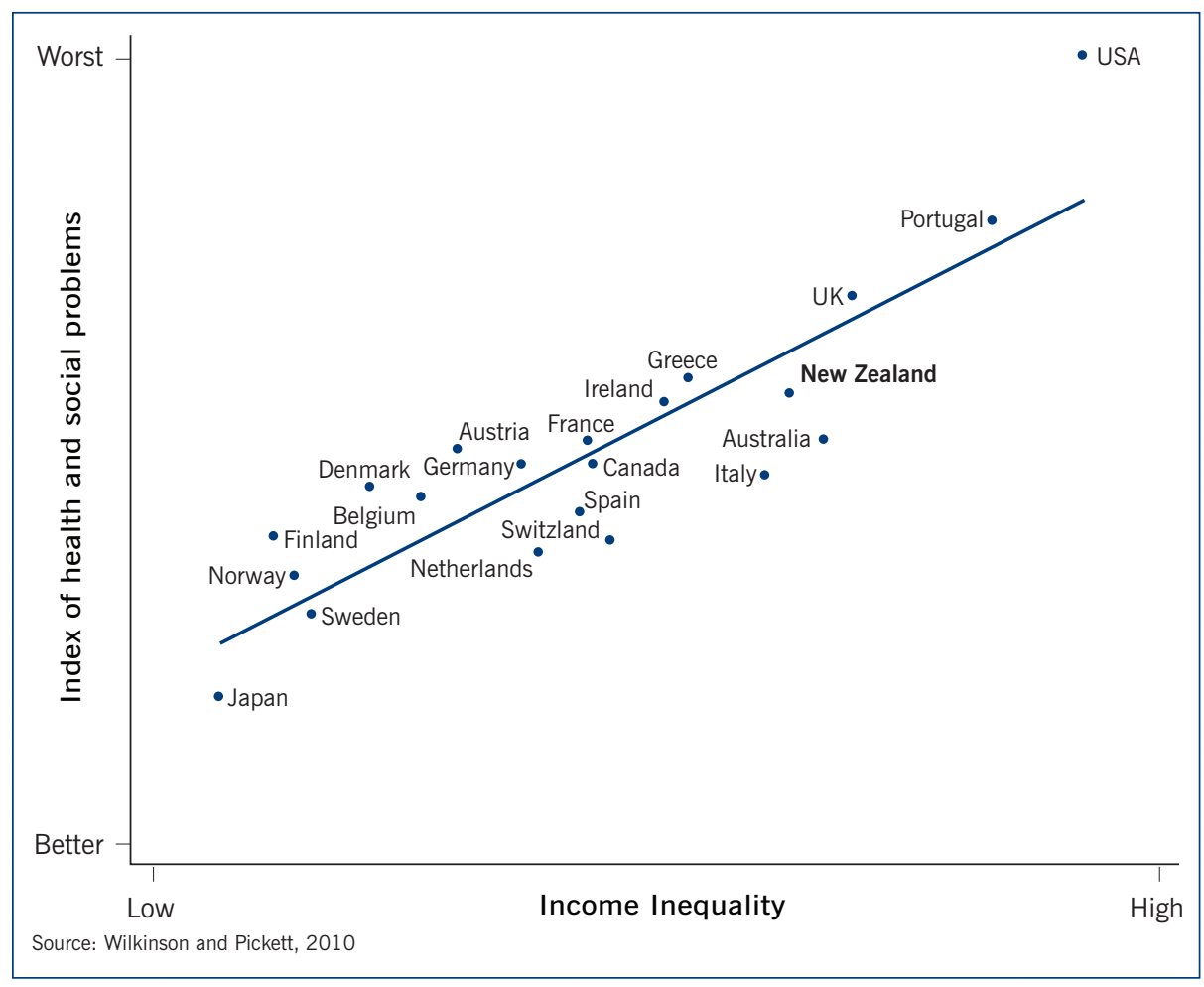

that poverty can be reduced in the short term and more likely that income inequality will grow further. Social service agencies are responding every day to the needs of people who bear the burden of our ongoing social problems (see NZCCS, 2011). There is an urgent need to design effective policies that will reduce the inequalities that are key contributors to these social problems.

High levels of income inequality have a pervasive effect which reduces or even negates the effectiveness of other policy interventions, such as targeted assistance programmes. The evidence is very strong that reducing economic inequality is an effective way to improve many key areas of health and social well-being. To quote the recent Marmot Review in Britain: 'Although there is far more to inequality than just income, income is linked to life chances in a number of salient ways' (Marmot, 2010). Reducing income inequality is not the only solution, but it is a powerful tool in the policy maker's tool kit; the policy options available to reduce inequality are discussed below.

Appeals to principles such as fairness, equity, justice and human rights or to enlightened self-interest highlight the fact that the debate about income inequality is also a test of our values as a society. Recent work on social attitudes to inequality sheds some light on where New Zealanders currently stand on these issues and suggests that there is support for reducing inequality. Evidence on its own does not settle the social and political debate, but failing to take account of a large and coherent body of evidence is undoubtedly a mistake.

\section{New Zealand and inequality}

Wilkinson and Pickett use ten measures in relation to income inequality for the IHSP. Figure 1 shows that New Zealand fits the international pattern among developed countries. Our high level of income inequality is associated with poorer health and social outcomes across our whole population.

New Zealand data were available for nine of the ten indicators. Data on social mobility are not available, although some limited data has been published recently (Gibbons, 2010). The overall rankings for New Zealand are shown in Figure 2.

Increasing inequality has been accompanied by worsening social outcomes:

- The prevalence of mental health problems in New Zealand is more than twice that in more equal countries such as Japan and Spain.
- The prevalence of obesity is rising and is more than double that of more equal countries such as Sweden or Norway. Obesity is a major risk factor for diabetes and cardiovascular disease, as well as some common types of cancer.

- Teenage pregnancies are higher. New Zealand's teenage birth rate is five times higher than that of countries with lower inequality, such Sweden.

- Imprisonment rates have doubled in this country since the mid-1980s and we lock up people at more than three times the rate of countries such as Japan and Finland.

- Overall life expectancy continues to rise, but New Zealand continues to rank poorly compared with more equal countries.

- Infant mortality is falling but our overall rate is high, and we compare poorly with more equal countries that have been able to reduce infant mortality at a faster rate.

- Maths and literacy average performance is high, but the same data shows that New Zealand has the highest level of inequality in education outcomes in the OECD (Treasury, 2011).

- Social mobility comparisons are not available because there is no internationally comparable evidence about the impact of income inequality on social mobility in New Zealand. A recent Treasury working paper using proxy data on social status was not

Figure 2: Index of health and social problems - rankings

\begin{tabular}{lcc}
\hline Key indicator & $\begin{array}{c}\text { NZ } \\
\text { ranking }\end{array}$ & $\begin{array}{c}\text { No of } \\
\text { countries }\end{array}$ \\
\hline Imprisonment & 20 & 23 \\
\hline Teenage births & 19 & 21 \\
\hline Obesity & 13 & 21 \\
\hline Infant mortality & 21 & 22 \\
\hline Mental illness & 9 & 12 \\
\hline Life expectancy & 16 & 24 \\
\hline Trust & 6 & 23 \\
\hline Maths and & 5 & 21 \\
literacy & 6 & 23 \\
\hline Homicide & No ranking
\end{tabular}


Figure 3: Gini Coefficient (Treasury, 2011)

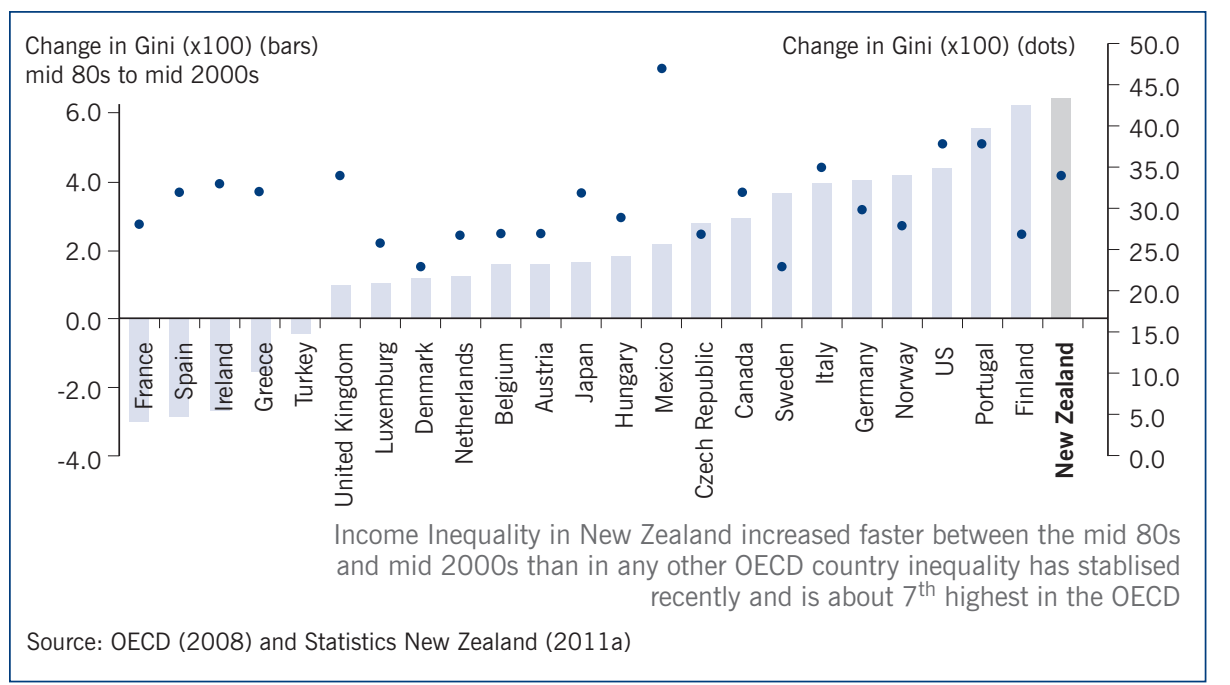

able to make any definitive conclusion (Gibbons, 2010).

Despite high income inequality, New Zealand performs well comparatively on other indicators:

- The level of trust is still high and not showing any signs of declining.

- Our homicide rate compares favourably with that in other countries; it is difficult, however, to conduct effective comparisons of other data on violence.

There is also a strong relationship between inequality and poverty. Continuing high inequality affects life chances, health, education and employment opportunities, and hinders effects to reduce poverty, especially child poverty (Dale et al., 2011). A detailed analysis of the source data and the New Zealand evidence is available on the website www.closertogether.org.nz.

\section{Income inequality in New Zealand}

New Zealand has one of the highest rates of income inequality among developed or wealthy countries, ranking 17 th out of the 21 countries ranked by Wilkinson and Pickett. Their index uses income inequality figures from the United Nations Human Development Report 2006, based on a 20:20 ratio which calculates the ratio of the richest $20 \%$ of income earners to the lowest $20 \%$ of incomes. Figures are household incomes after tax and transfers, adjusted for the number of people in each household.

Using a different measure (the Gini coefficient), inequality is seen to have increased faster in New Zealand than in any other OECD country over the two decades 1985-2005 (see Figure 3), while some OECD countries, such as France, Ireland and Spain, experienced reduced inequality (OECD, 2008).

Most of the increase was due to large rises in the incomes of the top $20 \%$ of income earners. The incomes of the bottom 20\% actually decreased over the two decades from the mid-1980s (Ministry of Social Development, 2010). Over that time, the rich got richer while the poor quite literally got poorer.

The increase in inequality occurred mainly between the mid-1980s and the mid-1990s. During the following decade the increase slowed. Since the mid-2ooos income inequality in New Zealand has decreased slightly, due largely to the impact of the government's Working For Families package (Perry, 2011), and the latest data show a drop in income inequality in the year to June 2010. Income inequality is still, however, embedded at rates well above those of the mid-1980s. The most recent comparative data from the OECD are from 2008-2009 and place New Zealand as around the tenth most unequal country in the OECD (Perry, 2011). This reflects the trend of increasing income inequality across the most of the OECD (OECD, 2011).

The effects of the October 2010 income tax cuts and related tax policy changes are not included in the latest New Zealand data. The increase in New Zealand Superannuation which was introduced in October 2008 as part of the 2008 tax changes appears to have contributed to a rise in income for the lower income deciles (where superannuitants are strongly represented). At the same time, there is a drop in the highest two income deciles, due to a loss of investment income (Perry, 2010).

\section{Critics of The Spirit Level analysis}

The critics who have challenged the methodology used by Wilkinson and Pickett, such as Saunders (2010) and Snowden (2010), have been well responded to (e.g. Noble, 2010). The statistical robustness of Pickett's and Wilkinson's work is strong and reliable. The Joseph Rowntree Foundation commissioned an independent review of the research on income inequality from a United Kingdom perspective. This review, conducted by Professor Karen Rowlingson from the University of Birmingham, confirms that there is a strong correlation between income inequality and the ten health and social indicators identified in the Index of Health and Social Problems (Rowlingson, 2011).

The extent of the causal relationship between income inequality and health and social problems is the real focus of debate, because this also influences the policy choices to respond to inequality. Causal relationships independent of other factors vary between indicators, but the effect is real. Rowlingson concludes that the evidence is strong about the negative impacts of income inequality, and, conversely, that there is virtually no evidence that increasing income inequality produces any positive effects (Rowlingson, 2011). In a similar vein, the New Zealand Treasury has acknowledged the importance of distributional issues in their work: 'While empirical evidence of causation remains inconclusive, both historical and contemporary events demonstrate that societies in which the benefits of growth are captured by a minority can face considerable social, economic and political upheaval' (Treasury, 2011).

\section{Drivers of inequality}

Income inequality across most of the OECD countries rose over the two decades from the mid-1980s to the mid-200os and appears to be converging at a common and higher average. In other words, other 
OECD countries are 'catching up' to New Zealand when it comes to increasing inequality. The OECD points to three broad drivers of the growing inequality developed countries (OECD, 2011):

- Globalisation, skill-based technological progress and institutional and regulatory reforms have all had an impact on the distribution of earnings.

- Changes in family formation and household structures have had an impact on households earnings and inequality (e.g. a rising number of single-person/sole-parent families).

- Tax and benefits systems have changed the distribution of household incomes.

The deregulation of the New Zealand economy over recent decades, especially in labour markets and trade protection, has opened up wage earners to direct competition from lower-income countries. This has had the effect of holding wage increases down for lowincome earners. Family structure in New Zealand is undergoing significant change, with a rising number of smaller households and sole-parent households. Our tax and benefits systems have undergone significant change: the top income tax rate has been reduced from $66 \%$ in the mid-1980 to $30 \%$ by 2011 , and benefits were reduced by up to $20 \%$ in 1991 and have been maintained at that level since.

The increase in income inequality in New Zealand over the past 25 years has been characterised by a large rise in the incomes of the top $20 \%$ of income earners and static or declining incomes for the lowest $20 \%$. Most households in the lowest $20 \%$ of incomes are either reliant on benefits or earning close to the minimum wage. While benefit levels have remained static, the pay rates of executives and chief executives have been increasing rapidly (see Boyle and Roberts, 2004; Strategic Pay, 2008).

\section{Māori inequality: a colonial legacy}

Distinctive to the New Zealand profile of inequality is the place of the tangata whenua. The Treaty of Waitangi guaranteed the legal rights of Māori and their ownership of lands and taonga -
Figure 4: Income inequality New Zealand (Gini coefficient)

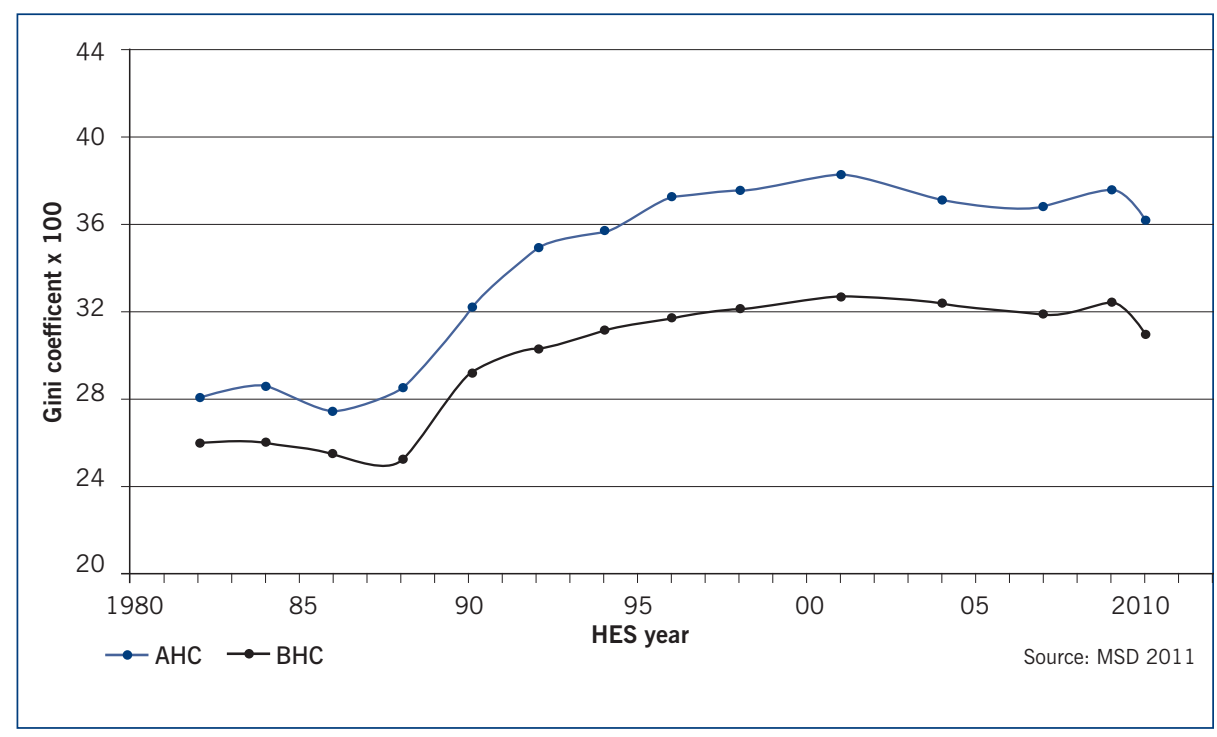

assets and material and cultural resources. But the legacy of colonial policies that disempowered Māori and alienated them from their land and economic base continues to define the position of Māori in New Zealand society. Despite positive developments in recent decades, Māori face massive challenges to building an economic, social and cultural base that can ensure well-being on terms that are acceptable to them. Māori bear an unfair burden of the health and social costs of inequality: they experience much higher rates of infectious disease among children, higher imprisonment rates, higher rates of mental illness and poorer education outcomes.

Indeed, the whole equality analysis is strongly criticised in some quarters as simply a continuation of the colonial mentality. Current ways of measuring inequality, poverty and disadvantage are seen to 'fail' Māori and Pacific children. The 'welfarism' of the current system, based on economic welfare, material well-being and limited human agency, is criticised (Henare et al., 2011). The current inequality measures compare Māori with non-Māori and represent a 'colonising' approach. Henare et al. call for a new 'dedicated well-being survey', with questions designed to reflect the capabilities approach promoted by Armatya Sen and used in measures such as the United Nations Human Development Index. The move to develop the Whānau Ora approach to social services as a holistic response based in Māori tikanga has been influenced by the desire to free Māori from this perceived dependence on a Pākehā-driven welfare model.

Policies to reduce income inequality

Deputy Prime Minister Bill English, responding to questions about income equality in Parliament on behalf of the prime minister, commented that he does not accept the view that New Zealand is a deeply unequal country, but, he said, 'the big issue about inequality is what we do about it' (New Zealand Parliament, 15 June 2011).

Achieving a sustained and meaningful reduction in income inequality (and wider socio-economic inequality) requires longterm policies aimed at raising the incomes of the lowest income earners while at the same time moderating increases of higher incomes. There are various policy options that could achieve this, and public debate needs to be informed by accurate information about these options and their impacts. Wilkinson and Pickett point out that the social and economic policies of, for example, Japan and Sweden are very different yet both have relatively low levels of income inequality and good social outcomes. The New Zealand experience of income inequality has common features with other developed economies, but also our own distinctive experience.

\section{Changing our attitudes to inequality}

Our social attitudes are caught in the tension between believing that people 
should take responsibility for themselves and thinking that the government should take responsibility to make sure everyone is provided for. Research from the New Zealand Values Survey reports that the majority of people prefer to blame the poor for their poverty. The survey respondents thought people were in need because of 'laziness' and 'lack of willpower' rather than because 'society treats them unfairly'.

On the other hand, nearly two thirds of people in the survey thought it was the government's responsibility to reduce the income difference between the rich and poor. They were also willing to pay more taxes to fund health services, education, pensions, job training and assistance for the unemployed and those on lower incomes (Carroll et al., 2011). These results align with other recent research by the International Social Survey Programme (2010), where a similar proportion of people said that income differences in this country are too large.

Research has also been undertaken in the United Kingdom on people's attitudes to inequality and how it might be possible to build a public consensus about tackling inequality (Bamfield and Horton, 2009). Both the New Zealand and UK research shows that people tend to have more negative and judgemental attitudes towards the poor than towards the rich. There does not appear to be much evidence to support the so-called 'tall poppy syndrome'. People tend to respect wealth as a measure of success and believe that it is mostly deserved. From the UK research it appears that people are more willing to support policies based on 'proportionate universalism', designed so that most people receive some benefit from government programmes as long as most benefit is directed towards the more disadvantaged. Therefore, the political challenge is to design policies which recognise that 'reducing inequalities is about fairness and self-interest' (Carroll et al., 2011).

\section{The three R's: restraint, regulation} and redistribution

Accordingly, the policy mix needed to address income inequality must negotiate the inherent tensions between individual self-responsibility and government responsibilities to ensure fairness. Broadly speaking, approaches to reducing inequality can be characterised as a combination of a culture of restraint, a commitment to good regulation and effective income redistribution. In Japan, a culture of restraint from those on higher incomes has been combined with a traditional commitment to ensuring comparatively modest differences in earnings between employees and their managers and executives. In contrast, Sweden has focused more strongly on redistributing income via taxation and government transfers, to ensure adequate income for those on lower incomes. Both Sweden and Japan share a historical commitment to ensuring high levels of employment. New Zealand can learn from these examples in finding its path to reducing inequality.

\section{Employment growth}

The current government believes that developing a strong economy that produces jobs and opportunity is its main priority. This can only reduce inequality, however, if people moving off benefits actually move into employment and earn more than what they would receive on a benefit. Paid employment also brings with it entitlement to transfers such as Working for Families tax credits. The effectiveness of increased employment in reducing income inequality is conditional on there being sufficient employment opportunities at rates of pay that actually do increase household incomes. It does not address income inequalities of those who are already in employment or the incomes of households relying on benefits for their income.

\section{Industrial democracy}

The decline in union membership has mirrored the rise in income inequality in New Zealand. The ability of workers to organise and bargain for better wages and conditions was greatly reduced after the introduction of the Employment Contracts Act 1991. Although the act was replaced by the Employment Relations Act 2000, which brought in some changes to improve opportunities for collective bargaining, union membership remains a fraction of what it was during the mid1980 os before the structural reforms were introduced (Department of Labour, 2009). A recent International Monetary Fund paper (Kumhof and Ranciere, 2010) notes the significance of employee bargaining power in achieving reductions in wage inequality.

Wilkinson and Pickett point to other forms of industrial democracy, such as shared employee ownership, that could act as vehicles for greater income equality by allowing employees direct share in the returns from their work.

\section{A culture of restraint}

Rediscovering a culture of restraint on the part of those in leadership in business, local and central government based on restraint, and transparency in setting remuneration for directors, executives and senior management could help change the inequality dynamics. In Japan it has proved possible for businesses to be highly successful while maintaining comparatively low differentials between the highest- and lowest-paid employees. It is clear that it requires a change in attitude from those in leadership to recognise the greater good in restraining differences to fair and reasonable levels. Organisations could explore using ratios in setting pay scales to ensure that the lowest paid are not left behind as executive pay increases.

\section{High Pay Commission}

Researchers have found that people greatly underestimate the differences in incomes in New Zealand, and we are tolerating ever greater difference (International Social Survey Programme, 2010). There is a need to talk about and agree on what level of income inequality is 'fair'. The independent High Pay Commission in the UK in its initial report asks whether the rise in the highest pay rates has led to us paying 'more for less' (High Pay Commission, 2011). Looking at the top 100 UK-listed company executives, the report charts the excessive increases in rewards that executives have been receiving that bear no relation to company performance. Chief executive remuneration has quadrupled in the past ten years, while share prices have fallen. There is little evidence of 'executive poaching' of executives by 
overseas companies, and neither does the risk involved in the roles appear to be sufficiently high to justify the huge increases in remuneration. Poor oversight by company boards and regulatory bodies of the remuneration of executives (and board members), and lack of shareholder power are identified as factors hindering attempts to restrain excessive growth in executive pay.

The commission is in the process of developing what it describes as a 'fair framework for fair pay' and it would be wise for New Zealand to consider a similar process. In New Zealand, the Remuneration Authority sets the salaries of Members of Parliament and judges and is required to consider 'fairness to the taxpayers or ratepayers who ultimately foot the bill' (Remuneration Authority, 2010). This requirement is not currently interpreted as including trying to avoid increases in income inequality or trying to reduce income inequalities.

\section{Regulation}

Forms of regulation and legislation that require decision makers to pay attention to reducing inequality can work either as a minimum 'safety net' underpinning agreed social consensus (e.g. minimum wage legislation), or can help 'raise the bar' and drive change in a positive direction. The minimum wage regulations can be used to reduce inequality. The Department of Labour reports on the impact of changes to the minimum wage on wage inequality, and its 2010 report notes that increasing the minimum wage to $\$ 15$ an hour would 'strongly improve' income distribution (Department of Labour, 2010).

It may be appropriate to explore regulatory means to manage public sector relativities through introducing maximum ratios between the highest and lowest paid. It has been pointed out that currently the mid-point of the top band of public sector salaries is around 11 times that of the bottom band (Brommell, 2010). It may be possible to come to a consensus on a lower maximum ratio.

\section{Fairness test}

Another regulatory approach could be to introduce a fairness test, a formal impact assessment of all policy and legislation that comes before Cabinet and Parliament, in the same way Treaty of Waitangi, gender and environmental impact statements are currently considered. It would involve an inequality impact assessment of policies and legislation (e.g. tax rises and spending cuts) to assess whether they would lead to an increase or decrease in inequality of incomes, assets or access to services. In a similar vein, the UK Equality Act 2010 required government agencies to show 'due regard to the desirability of exercising [their functions] in a way designed to reduce the inequalities of outcome which result from socio-economic disadvantage' (As it happens, this section of the act has since been repealed by the current coalition government.)

\section{Redistribution}

Redistributing income via the taxation system to share income and wealth more fairly involves a range of possible policy tools. Our current progressive tax system is already reasonably effective in reducing before-tax income inequalities, reducing them by about half (Perry, 2010). Changes to the tax system need to be analysed by asking whether they increase or decrease inequality. Treasury estimated that the 2010 tax package would not increase income inequality (Treasury, 2010). It would be a further step to require changes to seek actively to decrease income inequality.

The Working for Families system of tax credits is demonstrably the most successful policy of the past 25 years in reducing income inequality and poverty. Its introduction saw income inequality fall for the first time in two decades (Perry, 2010). Extending the benefits of this kind of programme to all families with children (i.e.to the unemployed and those on welfare benefits) would be another significant step by helping those on the lowest incomes. The $\$ 60$ per week in-work tax credit for families in employment with children could be changed to a child tax credit for all families with children, which would have an immediate impact of lifting the incomes of lowest-income families and reducing inequality.

Introducing a minimum income free of tax is another way to reduce inequality. The recent tax changes reduced the initial rate from $12.5 \%$ to $10.5 \%$, but in Australia, for example, the first $\$ 6,000$ of income is tax-free, so New Zealand still has a relatively high initial tax rate on the first dollar. Calculating the benefits of tax-free minimum income policies is made more complicated because of the impact of the transfers and tax credits low-income households receive. The Treasury's 2001 tax review looked at the issue and concluded that such a policy might well deliver more benefit to second-income earners in middle- and high-income households than it would to those on the lowest incomes.

\section{Universal basic income}

The idea of a universal basic income (UBI) has been promoted for many years without ever having been fully implemented (although Canada conducted a significant social experiment with it in some regions during the 1970s). The idea has been brought back into the public debate through a proposal for an Unconditional Basic Income (Morgan and Guthrie, 2011). A UBI has the advantage that it recognises and rewards work carried out by people in unpaid roles (such as child rearing and care of sick, disabled or older people). It offers the possibility of simplifying the complexities of the welfare system by effectively replacing all benefits with a UBI. The challenge is to set it at a level that lifts people out of poverty while also addressing the complexities of meeting additional welfare needs beyond the level of the UBI. The impact a UBI system would have on reducing inequality depends on the other tax and welfare policies with which it is combined.

\section{Widening the tax base}

The absence of any significant wealth taxes in the New Zealand tax system has repeatedly been identified as a major gap in ensuring tax equity (e.g. Tax Working Group, 2010). Widening the tax base to include some form of capital gains tax or other wealth taxes is an effective way to redistribute income and wealth and reduce the heavy reliance New Zealand has on income tax and GST. The challenge in designing a capital gains tax is to make it effective in raising revenue and limiting tax avoidance. 
GST and other consumption taxes affect most significantly those with the lowest incomes because they have to spend a higher proportion of their income. The 2010 increase in GST and associated rises in the cost of living hurt low-income families hardest. Reducing GST and/ or excluding essential food items from GST, or having a reduced rate for them, are policy options that would reduce hardship for low-income families and influence overall socio-economic equity, but by nature do not have an impact on income inequality because they are taxes on consumption, not income.

New forms of taxation need to be considered, including some form of financial transaction tax (such as the Tobin Tax). Such taxes target speculative financial transactions by taking a very small percentage (a fraction of a per cent) from every transaction. The low rate means it has no material impact on genuine transactions, but it could generate considerable tax revenue from the otherwise untaxed large speculative transactions.

\section{Opportunity costs are higher than redistribution costs}

The costs of doing nothing far outweigh the costs of increased tax transfers; this is the message of recent reports on child poverty (Grimmond, 2011; Dale et al., 2011). These two reports arrive at a similar figure for the overall costs to society and the taxpayer of leaving 200,000 children in poverty. At least \$6-8 billion (3.5-4.5\% of GDP) is a huge and long-term cost to our society. In the debate about the 'fiscal burden' of reducing inequality we do well to compare it to the multi-billion dollar price tag of not reducing inequality and poverty.

\section{Conclusion}

The evidence suggests that reducing income inequality in New Zealand will have a range of desirable social outcomes. But to achieve such a goal will require a careful mix of policies, efforts to promote changes in social attitudes (especially concerning the acceptability of very high incomes), and better access to goodquality paid employment, particularly for those on low incomes. Regulatory activity needs to complement voluntary restraint through active regulatory oversight of board and executive remuneration and use of minimum wage regulations to raise the lowest incomes. Redistributing income can be achieved through a widened tax base, including through effective wealth and transactions taxes that generate revenue sufficient to allow income transfers to those not able to earn sufficient income in the private market.

The evidence about the advantages of reducing income inequality is clear and many policy tools are available. New Zealanders generally share an underlying sense of fairness and appear willing to support a range of policies to reduce income inequalities. Hence, policy makers and those in political leadership can be confident that implementing policies to increase equality is not merely good policy and but will also enjoy public support.

\section{References}

Bamfield, L. and T. Horton (2009) Understanding Attitudes to Tackling Economic Inequality, Joseph Rowntree Foundation

Boyle, G. and H. Roberts (2004) CEO Compensation in New Zealand 1997-2002, 2004

Brommell, D. (2011) 'Income inequality and the economy of ideas', Policy Quarterly, 6 (3), pp.40-4

Carroll P. et al. (2011) 'The widening gap', Social Policy Journal of New Zealand, 37

Dale, M.C., M. O'Brien and S. St John (eds) (2011) Left Further Behind: how policies fail the poorest children in New Zealand, Auckland: Child Poverty Action Group

Department of Labour (2009) The Effect of the Employment Relations Act 2000 on Collective Bargaining, Wellington: Department of Labour

Department of Labour (2010) Regulatory Impact Satement: minimum wage review 2010, Wellington: Department of Labour

Grimmond, D. (2011) 1000 Days to Get It Right for Every Child: the effectiveness of public investment in New Zealand children, Wellington: Infometrics for Every Child Counts

Gibbons, M. (2010) Income and Occupational Intergenerational Mobility in New Zealand, working paper 10/06, Wellington: The Treasury

Henare, M. et al. (2011) He Ara Hou: the pathway forward, Wellington: Every Child Counts

High Pay Commission (2011), More for Less: what has happened to pay at the top and does it matter?, London: High Pay Commission

International Social Survey Programme (2010) Social Inequality in New Zealand, Massey University

Kumhof, M. and R. Ranciere (2010) Inequality, Leverage and Crises, working paper WP/10/268, International Monetary Fund

Marmot, M. (2010) Fair Society, Healthy Lives, report of the Marmot Review, London

Ministry of Social Development (2010) The Social Report 2010, Wellington: Ministry of Social Development

Morgan, G. and S. Guthrie (2011) The Big Kahuna: turning tax and welfare in New Zelaand on its head, Public Interest Publishing
National Equality Panel (2010) An Anatomy of Economic Inequality in the UK, report of the National Equality Panel

New Zealand Council of Christian Social Services (2011) Vulnerability Report, 9 (June) and 10 (September)

Noble, H. (2010) The Spirit Level Re-visited, www.equalitytrust.org.uk/ docs/hughnoblets/revisited.pdf

OECD (2011) 'Growing Income Inequality in OECD Countries: what drives it and how to tackle it', OECD forum, Paris, 2 May

OECD (2008) Growing Unequal: income distribution and poverty in OECD Countries, www.oecd.org/els/social/inequality

Pearce, J. (2011) An Estimate of the National Costs of Child Poverty in New Zealand, Auckland: Analytica

Perry, B. (2010) Household Incomes in New Zealand: trends in indicators of inequality and hardship 1982 to 2010, Wellington: Ministry of Social Development

Remuneration Authority (2010) Annual Report

Rowlingson, K. (2011) Does Inequality Cause Health and Social Problems?, Joseph Rowntree Foundation

Saunders, P. (2010) Beware False Prophets: equality, the good society and The Spirit Level, London: Policy Exchange

Snowden, C. (2010) The Spirit Level Delusion, Little Dice

Strategic Pay (2008) 'What price a good CEO?', www.strategicpay.co.nz

Tax Working Group (2010) A Tax System for New Zealand's Future: report of the Victoria University of Wellington Tax Working Group, Wellington: Centre for Accounting, Governance and Taxation Research, Victoria University of Wellington

Treasury (2001) Tax Review 2000: final report, Wellington: The Treasury Treasury (2010) 'Aide Memoire: distributional measures in relation to tax changes', www.treasury.govt.nz/publications/informationreleases/ budget/2010/tax/index.htm

Treasury (2011) Working Towards Higher Living Standards for New Zealanders, working paper 11/02, Wellington: The Treasury

Wilkinson, R. and K. Pickett (2010) The Spirit Level (2nd edn), London: Penguin 


\title{
Paul Callister and Judith Galtry
}

\section{Paid Parental Leave Policy - A Response to Maureen Baker}

\author{
In the August 2011 issue of Policy Quarterly, Maureen Baker sets out to \\ outline 'Key issues in parental leave policy'. One aim of the article was to \\ examine 'some of the continuing debates about paid parental leave'. However, \\ we argue that the article fails to advance debates about paid parental leave \\ in New Zealand, because: 1) it does not adequately engage with recent \\ national and international literature; 2) it lacks new empirical evidence; 3 )
} its theoretical basis is confused; and 4) no clear, new policy directions are promoted.

Baker's article is primarily a literature review. We therefore begin by outlining some of the key literature in this field that was overlooked. Most of this literature is easily accessible by using simple search techniques such as Google Scholar. Most is also freely downloadable.

An article of our own entitled 'Paid parental leave in New Zealand: a short history and future policy options' is a puzzling omission, given that it was published in 2006, also in Policy Quarterly. As indicated in the title, our article outlines the history of parental leave in New Zealand but, more importantly, suggests some future options, including some ideas that Baker subsequently discusses. This article puts into a wider historical context Baker's first sentence, which claims that 'in 2002, New Zealand employees gained access to paid parental leave'. While obviously not a universal scheme, a limited form of paid maternity leave was introduced in 1948 , which was available to some women in the public service. Over time, various other employers offered their own paid maternity, and sometimes parental, leave schemes. Then, in 1999, the parental tax credit was introduced as part of a wider Family Assistance package. This was available to qualifying families with a child or children born on or after 1 October 1999. Although the government at the time did not support the provision of European models of paid parental leave, it clearly wished to provide financial support to some new parents.

These developments indicate that parental leave policy in New Zealand developed over a long period and involved incremental change. Thus, a key policy question is whether future incremental change should continue to be supported or whether, in fact, new, more radical models of leave should be investigated.

In terms of relevant government reports, Baker mentions the report on parental leave by the Families Commission (2007), but fails to engage with two other significant government reports. One is the National Advisory Council on the Employment of Women's (NACEW) 2008 report entitled Priority Improvements to Parental Leave (NACEW, 2008). Both the Families Commission and NACEW reports recommend continuing incremental improvements to parental leave policy. Perhaps even more important is the Office of the Children's Commissioner's 2011 report entitled Through Their Lens: an inquiry into non-parental education and care of infants and toddlers (Carroll-Lind and Angus, 2011). This report engages with the difficult issue of determining specific policy configurations that are in the best interests of children in the first months and years of their lives. It raises complex issues of whether, especially in times of constrained government finances, support for the early months of a child's life should take the form primarily of parental leave rather than taxpayer supported early child care and education. This represents a more fundamental shift in thinking about parental leave and child care. Engagement with the recommendations of the government's Welfare Working Group would also have increased the policy relevance of Baker's article. In particular, this working group developed recommendations about parents' return to work relative to the age of the youngest child, an issue which is directly relevant to parental leave policies.

But we consider that there are also other important omissions. While referred to indirectly through mention of a television news item, there is no indepth engagement with the Child Poverty Action Group's important background paper Paid Parental Leave in New 
Zealand: catching up with Australia? (St John and Familton, 2011). It is necessary to consider Australia, if only because of New Zealand's strong labour market flow across the Tasman. Other studies that we believe the author should have considered include a number of our own, such as Galtry (1995, 1997, 2002 and 2003), Galtry and Callister (2005) and Callister and Galtry (2009). But even if Baker chose not to engage with the ideas presented in these particular studies, there are the New Zealand studies of James (2009), Forbes (2009) and Brough et al., (2009). Then there are relevant overseas studies. In Australia, Baird wrote an excellent article in 2004 setting out various typologies for parental leave at the same time that Australia was designing its own scheme. Finally, while the article notes the work of UNICEF when comparing leave schemes internationally, a significant paper by Ray et al., (2010) entitled Who cares? Assessing generosity and gender equality in parental leave policy designs in 21 countries is not referred to. Between these papers, all the issues that Baker raises in her own paper, as well as other important issues, are discussed. It would have been useful to build on this previous work.

\section{A lack of evidence and misleading statements}

Here, we focus on a number of statements about the labour market, as well as men and parental leave, that are not backed by evidence or seem to be misleading. As an initial example, highlighted on page 59, there is the statement 'leaving employment for child bearing and returning years later was feasible for women when labour markets were expanding in the 1960 , enabling them to re-enter more easily'. There is no evidence presented in support of this statement. In fact, it is unclear how entry into and exit from the labour market in the 1960 s could be assessed given that are no data sets, such as the current LEED data, which allow such rates to be calculated.1 However, indirect measures cast doubt on Baker's statement. While there was growth in employment for women in the 1960 s, even by the end of that decade just under $40 \%$ of women were employed. In contrast, by mid-2011 just under $60 \%$ of women were employed, with much of the growth occurring amongst women with young children. While these data do not indicate ease of re-entry, they do indicate a more expansive labour market for women in recent times. In addition, a raft of public and private policies supporting parents, including parental leave and subsidised child care, should now make it easier to re-enter employment after childbirth or adoption.

An example of a confusing, and again highlighted, statement is that 'parental benefits were introduced as a separate social programme which was available to women and men employees (genderneutral or at least transferable from mothers to fathers)' (pp.57-8). We query this description of gender neutrality. For comparison, it is highly unlikely that a policy would be regarded as 'gender neutral' if the benefit went directly to the male partner in a heterosexual couple but was able to be transferred (if he so wished and it was mutually agreed) to his female partner. This current New Zealand policy configuration appears to be a double-edged sword for the goal of gender equity, as it attributes not only decision-making power to the mother, but also, by implication, the responsibility for child-rearing. It is therefore curious that this policy is sometimes perceived as a feminist policy (as discussed later). What Baker also fails to mention is that this transferable benefit disadvantages couples where the man is eligible through his work record but the woman is ineligible and thus unable to transfer the right to 'parental' leave to him.

In relation to fathers' rights to leave, Baker notes a case taken in Canada by a father who argued that biological fathers should have the same rights as adoptive fathers. It would have been useful if Baker had also mentioned the long campaign by New Zealand fathers' groups to have equal rights with mothers to paid parental leave. In our 2006 Policy Quarterly article it was noted, for example, that '[a] formal complaint was also lodged with the Human Rights Commission on the grounds that the legislation discriminated against biological fathers, as they did not have an independent right to take a period of paid leave'.

In her discussion of men taking (or not taking) leave, Baker also fails to refer to the Department of Labour's finding that most women do not want to pass on their parental leave. There are various reasons for this, including that most new mothers in New Zealand breastfeed in line with national and international health guidelines (Galtry, 2000). Although Baker mentions lactation once in the article, she does not engage with the complexity this poses for leave-sharing, especially when the duration of paid parental leave is relatively short, as in New Zealand.

Finally, on page 61 Baker mentions that mothers are less able than fathers to take on high-paying and secure jobs. But this assertion needs to be examined. Increasingly, women are better educated than men and many women now have partners who are less educated than themselves (Callister and Didham, 2010). Prior to their having children there are few constraints to women taking jobs that pay more than those of their male partners. This shows up in the lack of a significant gender pay gap among people under 30 years of age (Ministry of Social Development, 2010).

The most significant pay gap occurs after women and men have children. What researchers and policy makers need to grapple with is why many women and men continue to adopt traditional gender roles once children are born. Instead, Baker portrays labour markets as being far friendlier to men than women. But, given changes in global employment, both men and women with low formal skills face major barriers to finding 'decent' work. This is one reason why, in a number of our own articles about parental leave, we suggest a universal payment, so that work history, which is increasingly uncertain for some groups, does not determine eligibility.

\section{Lack of a coherent theory}

In her introduction Baker claims that her article is written from a 'feminist political economy perspective'. Later she notes the arguments put forward by 'feminists and progressive reformers'. 
But the particular strain or strains of feminist theorising to which she refers are never clearly identified. One of the complexities of parental leave debates is that many feminist perspectives have been applied to them, ranging from clearcut arguments about the importance of 'equal treatment' for women and men to equally strong views about the need to support 'difference', especially around pregnancy, childbirth and breastfeeding (Galtry, 2000). Baker uses a range of feminist perspectives but fails to outline clearly which she is using at any particular time. In addition, as already noted, a much clearer depiction of parental leave typologies would have been useful. The article could have usefully identified and examined, for example, the differing objectives and construction of various maternity/parental leave schemes and their gendered effects. Instead, it concludes with vague calls for policy that supports gender equity in both the workplace and the home.

\section{Conclusion}

Debates about parental leave are important, especially in the period before an election. Parental leave is a critical component of any strategy for investing in children and requires rigorous analysis and debate. But through a lack of acknowledgement of past debates and unclear policy formulation, Baker's article fails to take such discussions forward. It is a shame such an important opportunity was wasted.
The Linked Employer-Employee Data Research Programme (LEED) is a multi-year project that is generating new research findings about workers and firms using linked employer and employee data. These data have been used to investigate a wide range of research questions, including re-entry to paid work for parents following a period of paid parental leave.

\section{References}

Baird, M. (2004) 'Orientations to paid maternity leave: understanding the Australian debate', Journal of Industrial Relations, 46, pp.259-74

Brough, P., M. O'Driscoll and A. Biggs (2009) 'Parental leave and workfamily balance among employed parents following childbirth: an exploratory investigation in Australia and New Zealand', Kōtuitui: New Zealand Journal of Social Sciences, 4, pp.71-87

Callister, P. (2002) 'Should job protection and income support for new parents be separated? Policy options in a US and New Zealand context', Community, Work \& Family, 5 (3), pp.279-99

Callister, P. and R. Didham (2011) 'The "meet market": a research update', New Zealand Population Review, 36, pp.103-115

Callister, P. and J. Galtry (2006) 'Paid parental leave in New Zealand: a short history and future policy options', Policy Quarterly, 2 (1), pp.38-46

Callister, P. and J. Galtry (2009) "Baby bonus" or paid parental leave: which one is better?', Social Policy Journal, 34, pp.1-11

Carroll-Lind, J. and J. Angus (2011) Through Their Lens: an inquiry into non-parental education and care of infants and toddlers, Office of the Children's Commissioner, http://www.occ.org.nz/_data/assets/ pdf_file/0017/8108/CC_Through_their_lens_21032011.pdf

Chapple, S. (1994) HLFS-consistent Labour Market Data, working paper 94/16, Wellington: New Zealand Institute of Economic Research

Families Commission (2007) It's About Time: towards a parental leave policy that gives New Zealand families real choice, research report 3/07, Wellington: Families Commission

Forbes, K. (2009) 'Paid parental leave under (New) Labour', Social Policy Journal of New Zealand, 34, pp.12-24

Galtry, J. (1995) 'Breastfeeding, labour market changes and public policy in New Zealand: is promotion of breastfeeding enough?', Social Policy Journal of New Zealand, 5, pp.2-16
Galtry, J. (1997) 'Sameness and suckling: infant feeding, feminism, and a changing labour market', Women's Studies Journal of New Zealand, 13 (1), pp.65-88

Galtry, J. (2000) 'Suckling in silence: breastfeeding and paid work in New Zealand, the United States and Sweden', PhD thesis, Victoria University of Wellington

Galtry, J. (2002) 'Child health: an underplayed variable in parental leave and early childhood education policy debates?', Community, Work \& Family, 3, pp.257-78

Galtry, J. (2003) 'The impact on breastfeeding of labour market policy and practice in Ireland, Sweden, and the United States', Social Science \& Medicine, 57, pp.167-77

Galtry, J. and P. Callister (2005) 'Assessing the optimal length of parental leave for child and parental well-being: how can research inform policy?', Journal of Family Issues, 26 (2), pp.219-46

James, J. (2009) 'Facilitating fertility and paid work: contemporary family-friendly policy initiatives and their social impacts in Australasia', Social Policy Journal of New Zealand, 34, pp.25-39

Ministry of Social Development (2010) 'The social report', Ministry of Social Development, http://www.socialreport.msd.govt.nz/paid-work/ median-hourly-earnings.html

NACEW (2008) Priority Improvements to Parental Leave, Wellington: National Advisory Council on the Employment of Women

Ray, R., J.C. Gornick and J. Schmitt (2010) 'Who cares? Assessing generosity and gender equality in parental leave policy designs in 21 countries', Journal of European Social Policy, 20 (3), pp.196-216

St John, S. and A. Familton (2011) Paid Parental Leave in New Zealand: catching up with Australia?, Child Poverty Action Group background paper 01/11, http://www.cpag.org.nz/assets/Backgrounders/ Backgrounder.PPL.pdf 